\title{
EDPACS
}

The EDP Audit, Control, and Security Newsletter

\section{SPOTLIGHT ON LGBT IN MALAYSIAN ONLINE NEWSPAPERS: INSIGHTS FROM TEXTUAL ANALYTICS}

\section{Su-Hie Ting, Kee-Man Chuah, Collin Jerome \& Audrea Johnson}

To cite this article: Su-Hie Ting, Kee-Man Chuah, Collin Jerome \& Audrea Johnson (2021): SPOTLIGHT ON LGBT IN MALAYSIAN ONLINE NEWSPAPERS: INSIGHTS FROM TEXTUAL ANALYTICS, EDPACS, DOI: 10.1080/07366981.2021.1958733

To link to this article: https://doi.org/10.1080/07366981.2021.1958733

曲 Published online: 09 Aug 2021.

Submit your article to this journal $₫$

View related articles $Ґ$

View Crossmark data $\nearrow$ 


\section{SPOTLIGHT ON LGBT IN \\ MALAYSIAN ONLINE \\ NEWSPAPERS: INSIGHTS FROM TEXTUAL ANALYTICS}

\author{
SU-HIE TING, KEE-MAN CHUAH, COLLIN JEROME \\ AND AUDREA JOHNSON
}

\begin{abstract}
The study examined aspects that were spotlighted in news articles on LGBT in Malaysian online newspapers using textual analytic approach. The specific objectives of the study were to (1) determine the aspects of LGBT highlighted in news articles based on the frequency of top ranked words; and ( 2 ) analyse the positive and negative coverage of LGBT in the four online newspapers. The Linguistic Inquiry and Word Count (LIWC) software was used to extract high frequency content words in four online newspapers (The Star Online, Free Malaysia Today, MalaysiaKini, and Astro Awani Online). The analysis revealed controversy surrounding LGBT. The aspects of LGBT highlighted in news articles were largely negativity and non-permissiveness towards LGBT, the association of LGBT with Malay and Muslim, and the quotation of government and ministerial sources to comment on LGBT. The prominence of government-linked sources drowned out the voice of activists and advocates of LGBT rights. The textual analytic software analysis also revealed that Astro Awani was markedly different from the other three newspapers in its event-focused reporting on LGBT, mainly because it is a news portal affiliated to a television channel. Astro Awani's news articles on LGBT were mostly negative, but the other three newspapers attempted to balance positive and negative coverage on LGBT. The study showed that data mining of news articles using textual analytic software can reveal salient aspects of the LGBT issue that is given attention by the newspapers, and may indicate how media shapes readers' attitudes towards LGBT.
\end{abstract}

\section{INTRODUCTION}

Coverage of Lesbian, Gay, Bisexual and Transgender (LGBT) in newspapers falls broadly into positive and negative coverage. Positive coverage of LGBT revolves around the rights of LGBT, which is defined by Chomsky and Scott (2008, p. 2) as issues of "adoption, marriage, and involvement in community activities".
IN THIS ISSUE

- SPOTLIGHT ON LGBT IN MALAYSIAN ONLINE NEWSPAPERS: INSIGHTS FROM TEXTUAL ANALYTICS

Editor

DAN SWANSON

\section{Editor Emeritus} BELDEN MENKUS, CISA

Taylor \& Francis

\section{CELEBRATING OVER 4 DECADES OF PUBLICATION!}

